\title{
GENDER EQUALITY POLICIES AND GENDER MINDSET IN KOSOVO
}

\section{KIMETE CANAJ}

\begin{abstract}
:
This paper discusses gender equality concerns within higher education, politics and examines the gender related policies introduced in Kosovo. Gender differences emerge in primary and secondary education partly because traditional gender roles and stereotypes tend to be reproduced in schools. These differences are then reflected in and further strengthened by the choices made and opportunities open to women and men at the higher levels of education and vocational training. Therefore, it is important to examine whether and how Kosovo attempt to combat these inequalities. Kosovo have designed policy and have supported projects targeting gender inequalities in education and incorporate specific gender equality provisions in legislation or in governmental strategies and make it compulsory for political parties to create their own gender equality policies. In politics are obliged 30\% quotas for female places in Assembly, but in other Higher management positions are mostly males, for example in 6 public Universities all rectors and most deans are male. In Higher Education Institutions are two main concerns in Kosovo with respect to gender inequality in higher or tertiary education: horizontal and vertical segregation. Firstly, it is concerned about horizontal segregation, that is, the problem that women and men choose different fields of study in higher education, with women being under-represented in engineering and science. Secondly, it is also concerned about vertical segregation. This problem is related to the currently existing 'glass ceiling' in tertiary education: while women outnumber men amongst higher education graduates. They participation in Higher Education its slightly increased at the doctoral level, and there are even fewer women amongst academic staff in universities, or none of them as Rector but few of them as Vice-Rector at the managerial level in universities. These two issues and the policies intended to deal with them will be discussed in this paper.

1) University of Prishtina "Hasan Prishtina" since 1970, University "Ukshin Hoti" Prizren since 2010, University "Haxhi Zeka" Peja, University "Isa Boletini" Mitrovica, University "Kadri Zeka" Gjilan und University "Fehmi Agani" Gjakova since 2011
\end{abstract}

\section{Keywords:}

Gender Equality Policies, Gender Mindset, Kosovo, Gender \& Education,

JEL Classification: 124, 128, Z19

\section{Authors:}

KIMETE CANAJ, University "Ukshin Hoti" Prizren, Kosovo, Email: kimete.canaj@uni-prizren.com

\section{Citation:}

KIMETE CANAJ (2021). Gender Equality Policies and Gender Mindset in Kosovo. International Journal of Social Sciences, Vol. X(1), pp. 1-16., 10.52950/SS.2021.10.1.001 


\section{Methodology of work}

The methodology of work in this paper is based on three main phases, starting from the examination of the official policy documents as well as primary and secondary legislation related to the education and gender issues. This obviously included reports, studies and assessments published by international organizations (EU, OSCE, USAID, UNDP, Council of Europe, UN) and the reports and publication from the government (Ministry of Education, Science and Technology ${ }^{1}$, Presidents Office and Agency on Gender Equality - Prime Ministers Office ${ }^{2}$ ) other local authorities and a comparative data with a selection of the local non-governmental organizations active on education and gender equality themes. The second phase consisted of a set of structured interviews with key staff in central units of the Education and gender equality system, and especially the Advisory Office for Good Governance, Education, Human Rights, Equal Opportunities and Gender as well as the Gender Equality Agency (AGE). Gender Equality studies from different Authors and the suggested literature that to succeed in global roles, one needs a global mindset, and we examine gender differences in global leadership self efficacies in a random sample. Javidan/ Bullough \&Dibble (2016) using the Global Mindset Inventory found that women demonstrated stronger global leadership profiles in regard to passion for diversity, intercultural empathy and diplomacy. Conversely, men tended to show strong global leadership self-efficacies regarding global business savvy, cosmopolitan outlook, and interpersonal impact.

The third phase was the comparative analyses of data and recommendation for the next step in the education and gender equality.

\section{Policy and Legal Framework}

Education, Human Rights and Gender are bestowed in advance of government policy. The Constitution of the Republic of Kosovo, as the highest law of the land, establishes the Rights and Fundamental Freedoms of individuals. The Constitution also makes 6 United Nations and 2 Council of Europe instruments directly applicable, in spite of Kosovo not being yet a part of the Council of Europe, thus reinforcing the content of this comprehensive bill of rights ${ }^{3}$. The Kosovo bill of rights includes both negative rights requiring the State not to interfere (e.g. right to privacy, freedom of expression) and others requiring it to take positive measures (e.g. to secure equal

\footnotetext{
1 Kosovo Program for Gender Equality 2020- 2024 AGE Kosovo Program for Gender Equality 20202024.pdf (rks-gov.net) (5.12.2020)

${ }^{2}$ Agency on Gender Equality (AGE) - Office of the Prime Minister (kryeministri-ks.net) (5.12.2020)

3 The listed instruments include: Universal Declaration on Human Rights, European Convention on Human Rights (ECHR), International Convention on Civil and Political Rights (ICCPR), Framework Convention on the Protection of National Minorities, Convention on the Elimination of all Forms of Racial Discrimination (CEAFD), Convention on the Elimination of all Forms of Discrimination Against Women (CEDAW), Convention on the Rights of the Child (CRC) and the Convention against Torture and other Inhuman Treatment and Punishments (CAT). However, the Constitution fails to include the International Covenant on Economic, Social and Cultural Rights and the European Social Charter probably due to their financial implications.
} 
access to right to education, health etc.). These include the right to "gender equality as a fundamental value for the democratic development of the society, providing equal opportunities for both female and male participation in the political, economic, social, cultural and other areas of societal life".

The role of Government policy in protecting and fulfilling rights concerns therefore the choice of instruments for their safeguard and where necessary, the positive measures for their fulfilment. The Programme of the Government $\left(2008-2011,2011-2014 ; 2014-2018^{4}, 2018-2022\right)$ points out that "with the approval of the Constitution of Republic of Kosovo, all social and political development processes will be deeply based on the principles and provisions of the Constitution by guaranteeing ...equality of all citizens before the law"5."The government will adopt new laws with a view of supplementing the legislation for protection of human rights. This will include the law on gender equality ${ }^{6}[\ldots]$ The Government will be focused on strengthening the role and position of women in society, drafting and implementing appropriate policies for their economic strengthening with inter - sector approach followed by proper resources for implementation. The Government will continue to strengthen institutional mechanism for gender equality" 7 . Legally the Gender Equality in Kosovo is improved but the reality is different.

This paper will present the actual and real situation of gender equality and the recommendations how to improve the gender equality in the higher position of government and the management of Higher Education Institutions.

Education is the basic key to Kosovo's future development as a successful, stable and prosperous country. But based on EU- Report the quality of education remains poor. "In the 2018 OECD Programme for International Student Assessment (PISA), Kosovo again (as in 2015) ranked third from bottom. Kosovo also participated in the 2019 Trends in International Mathematics and Science Study (TIMMS), as well as in the 2021 Progress in International Reading Literacy Study (PIRLS). The authorities launched a wide-ranging curriculum reform in 2012, focusing on students and their competencies. While it was introduced to all schools in 2017, progress is hampered by a lack of suitable textbooks, teaching materials and teacher training"8.

Gender equality is essential to the success of general society and of the economic development. Kosovo cannot get ahead if the women are left behind. EU Programmes and USAID are providing grants to support women in economic empowerment, education, combating violence, participation in politics, and even sports. Supporting the female entrepreneurs supports not just a family, but it

\footnotetext{
4 Government Program 2014-2018. Government Webpage: http://www.kryeministriks.net/repository/docs/Programi i Qeverise 2015-2018 10 mars.pdf (15.11.2020)

${ }^{5}$ Chapter 2 of the Program of the Government of the Republic of Kosovo 2008-2011, Office of the Prime Minister, April 2008.

6 Law on Gender Equality Annex-LAW NO. 05 L-020 ON GENDER EQUALITY.pdf (equineteurope.org) (5.12.2020)

7 http://www.kryeministri-ks.net/repository/docs/Government Programme 2015-2018 eng 10 mars.pdf $\quad$ pg. 34 (15.10.2015)

${ }^{8}$ kosovo report 2020.pdf (europa.eu) (5.12.2020)
} 
empowered an entire community. It is a joint-responsibility, and one that can help entire communities. On the political stage, it has been proved that engaging women can help make government institutions more representative and more effective. Women bring a unique perspective to decision-making in peace and security, to end conflict or to prevent conflict. It turns out that we are good at collaborating, communicating, and consensus-building. And these are the skills that the $21^{\text {st }}$ century needs.

In the level of the implementation of the Government Programme, such as the multi-year European Partnership Action Plan and the Government Annual Work Plan which identify several measures that are relevant to advance the gender equity and human rights envisaged in the Constitution. The implemented measures appear to include a special focus on two cross-cutting themes: - The rights of members of national communities (measures on participation in and access to public services) and the - Equality between men and women (particularly through gender mainstreaming measures in all areas). ${ }^{9}$

Education and Human Rights are guaranteed with the Constitutions ${ }^{10}$ which is very advanced Constitution in Europe:

- The right to education (access to primary and secondary education, quality of education, responsiveness to the labour market, vocational training);

- The right to work (measures on reduction of unemployment, and non-discrimination in access to employment);

- The right to health (measures on support to people with special needs; elderly; assistance to victims of violence/trafficking);

- The right to personal security (anti-trafficking initiatives, measures concerning capacitybuilding in the security services, and detention centres);

- $\quad$ The right to privacy (data protection measures);

- $\quad$ The right to information (measures on access to publically held information).

In Kosovo are installed mechanisms to achieve the gender equality in central level through:

- Office of Gender Equality at the Prime Minister Office.

- The action Plan of European Partnership

- Ombudsman office - Gender Unit

- Civil servants on Gender Equality in central institutions

- Inter-ministerial council on Gender Equality

- Unit for gender issues - in all Local Authorities

- Gender Center at the University of Prishtina

\footnotetext{
${ }^{9}$ Functional Review of Human Rights and Gender Equality System

10 Constitution of Republic of hosovo.

ks.net/zck/repository/docs/Constitution.of.the.Republic.of.Kosovo.pdf [30.10.2015]
} 
In Kosovo, a first woman President of Kosovo from 2011-2016 (Atifete Jahjaga). She was the first non-political candidate and the youngest women to become the head of the state, and the first Kosovo women as Mayor Mimoza Kusari from 2013-2017.

Kosovo women are underrepresented in local governments, with only $4.4 \%$. Kosovo has also, when passing the Law on General Elections included a $30 \%$ quota, both, for municipal ${ }^{11}$ and national ${ }^{12}$ assemblies.

But the fully implementation of Law on Gender is a challenge and an obstacle on issues of ownership of property from the patriarchal family society or is very difficult to change the mindset due to the gender equality, the patriarchal society cannot accept that the women can be a powerful lieder accepted and respected from the general patriarchal society.

\section{Education and Gender Equity in Kosovo}

Kosovo is concerned about the fact that the proportion of men and women vary considerably between different areas of study in tertiary education. Despite the relatively small differences between the attainment of girls and boys, especially in the fields of mathematics science and engineering this pattern of inequality is similar among students and graduates and is fairly consistent throughout Kosovo Higher Education Institutions. Differences in the choice of academic discipline by young people can be attributed to traditional perceptions of gender roles and identities as well as the wide acceptance of the cultural values associated with particular fields of study. For example, while some fields, especially science and engineering, are widely regarded as 'masculine' and suitable for men, other fields of study, most importantly care-related ones like education or health, are defined as 'feminine' and appropriate for women. This makes it difficult for members of the minority sex to enter these fields without challenging the dominant culture or their own self-perceptions.

\subsection{Horizontal Segregation}

In Kosovo exists differences between male and female graduates by field of study. The largely female-dominated fields are education and training, health and welfare and humanities and arts. At the public $\mathrm{HEl}$ at the University of Prishtina and University of Prizren in academic year $2011 / 2012^{13}$ are $53 \%$ female and in academic year $2019 / 2020$ are $58 \%{ }^{14}$

11 Law on Local Election in the Republic of Kosovo, Article 8, available at: http://www.kuvendikosoves.org/common/docs/ligjet/2008_03-L072_en.pdf , Law on General Elections, Article 111.6. [18.01.2021]

12 The Law on General Elections in the Republic of Kosovo, Article 27, available at: http://www.kuvendikosoves.org/common/docs/ligjet/2008_03-L073_en.pdf.

13 OECD Report on Innovation 2013:59)

${ }^{14}$ Kosovar Statistics SHQIP ASK.pdf (rks-gov.net) (5.12.2020) 
The only female-dominated fields are education and training (81,5\% women) and arts and humanities $(67 \%)^{15}$ and the relatively low number of female graduates in engineering and science at the University of Prishtina is $40 \% .{ }^{16}$

Literacy continues to be a gender and age issue in Kosovo. Females are more than two times as likely to be illiterate as males $(7.5 \%$ versus $3.3 \%$ in urban areas, and $11.3 \%$ versus $5.5 \%$ in rural areas). The proportion of women in the labor force is quite half of men. During the last five years this percentage has been reduce from 30 to 29 for women and from 68 to 67 for men. • Unemployment rate for women is 56 percent and for men is 41 percent. ${ }^{17}$ According to the results of the LFS, in Quarter 1 2019, the unemployment rate is $26.9 \%$. The most pronounced unemployment is in females by $\mathbf{3 1 . 6 \%}$, compared with males, $25.4 \%$. The most pronounced unemployment rate is in the age group $15-24$ with $50.6 \%{ }^{18}$

- Women are working more at professional levels such as professional, servant and technicians jobs. Meanwhile men are doing all types of professions. Women are working more in the education, health, trade and Public Administration. Women have $33.3 \%$ percent of the parliamentarian seats in the legislation period 2010-2014.

Based on the study of Kim, Atwater, Jolly e.a. $(2019)^{19}$ the Vicious Cycle of Work Life is same in Kosovo too, women remain underrepresented in upper management positions. The question is why women might be less likely than men to be promoted, even in Higher Education Institutions with high gender equality climates. The Work Effort Versus Career Development Effort the same vicious cycle of work "that women and men used different strategies regarding how to direct their effort to achieve promotions. Women with high self-efficacy under high gender equality climate focused on increasing work effort, whereas men in similar situations focused on increasing career development effort. We also found that only career development effort was positively related to promotion, whereas work effort was positively related to work stress and turnover intentions, and negatively associated with job satisfaction. Our results suggest that different effort strategies lead women to become caught in a vicious cycle of working hard and earning only unpleasant consequences." 20

As general Information from EU Countries comparing with the Kosovar statistics:

In education and training, on average, $80 \%$ of graduates are women in the EU-27, and women constitute the majority in all countries analysed. In Kosovo on average $53 \%$ are women (statistics from academic year 2012/2013). In Estonia, Italy and Latvia, the proportion of women is especially high; only one out of ten graduates in these fields is a man. In the area of health and welfare, $76 \%$ of graduates are women and they form the majority in all countries (except Turkey),

\footnotetext{
15 The same statistics are in 27EU Countries

${ }^{16}$ The statistics are collected from the author for academic year 2012/2013.

17 Kosovo Statistics "Women and Men in Kosovo" 2009

18 Kosovo Agency of Statistics: Labor Force Survey in Kosovo, Q1 2019 | (rks-gov.net) (5.12.2020)

${ }^{19}$ Kim, K.Y., Atwater, L. Jolly, Ph.M., Kim, M., Baik,K. (2019)

20 The Vicious Cycle of Work Life: Work Effort Versus Career Development Effort - Kyoung Yong Kim, Leanne Atwater, Phillip M. Jolly, Myungsun Kim, Kibok Baik, 2020 (sagepub.com) [18.01.2021]
} 
especially in Estonia, Latvia and Iceland (approximately $90 \%$ or more). The area of humanities and arts also has a majority of women graduates - approximately $70 \%$. In Estonia and Latvia, males make up only one in five of the graduates in this area.

In the area of social science, business and law, which have by far the highest number of students and graduates, women are in a slight majority. In the EU-27, on average, approximately $60 \%$ of graduates are female, in Kosovo are approximately $51 \%$. In the Baltic countries and Hungary, the proportion of women graduates in these fields is higher than $70 \%$.

By contrast, in the area of engineering, manufacturing and construction, men are markedly dominant; only one out of four graduates is a woman. Men are over-represented in all countries, especially in Germany, Ireland, Cyprus, the Netherlands and Austria, where the proportion of female graduates is less than $20 \%$ and in Kosovo is less than $22 \%$. The area of science, mathematics and computing is slightly male dominated - approximately $60 \%$ of graduates are men. It is worth noting, however, that in Bulgaria and Romania, the general pattern is reversed with a majority of female graduates in this field.

There are large country variations regarding the gender composition of graduates in the area of

services, while the agriculture and veterinary area has about equal distribution of women and men..

However, these areas are rather small, producing less than $5 \%$ of total graduates in Europe and in Kosovo less than $2 \%$.

Most countries with gender equality policies in higher education have the primary goal of combating horizontal segregation and the gender imbalance in the choice of academic discipline by women and men. Almost all of these policies and projects target girls or women; only a minority of programmes focus on the choices made by boys or men.

There are two main policy instruments aiming at changing the traditional choices made by women (and sometimes men). Firstly, educational or vocational guidance is provided in secondary schools. Secondly, there are awareness-raising projects involving higher education institutions. These projects can be initiated or financially supported by ministries or governments. In most cases, their aim is to attract more women to the fields of science, mathematics and computing as well as to engineering, manufacturing and construction. The most common practices include the organisation of university open days or the granting of special awards to female students. In Kosovo are not such special awards or any open days, or any support to attract more female in the field of science, mathematics and computing, and such fields of studies are very important for the economy development and innovation in the industry with the aim of decreasing the unemployment rate in Kosovo.

For some science study fields are no entrance exams like in some other medicine or social fields, where is noted a high demand and high competition for the student place on public Higher Education Institutions such as medicine or psychology, law and economics. 
In Austria and Sweden the Ministry has established national centres in mathematics and in science which, together with other partners, have a mandate to encourage and recruit students, especially women, into science subjects, but this is not the case in Kosovo.

\subsection{Vertical segregation}

There are notable gender differences regarding participation in and graduation from tertiary education (ISCED 5-6). In general, more women than men are enrolled in higher education In Europe (see EACEA/Eurydice 2009a, Figures C16 and F6). The exception is Turkey, where only $43 \%$ of students are women. On average in the EU-27, women comprise $55 \%$ of students enrolled at tertiary level; in Iceland the figure rises to $64 \%$. Across Europe even higher proportions of women complete their studies and graduate: $59 \%$ of graduates are female. In Estonia and Latvia, the proportion of females who graduate is even higher, approximately $70 \%$.

The average proportion of women enrolled in tertiary education has been gradually increasing over recent years in the EU-27 (2\% increase from 1998 to 2006). This pattern is similar in most European countries, with an increase of more than 5\% in the Czech Republic, Malta, Romania and Slovakia. Bulgaria and Cyprus were the only countries where female participation rates decreased between 1998 and 2006 (7\% and 4\% respectively). The proportion of female graduates rose even faster, with an increase of $4 \%$ on average across the EU-27 from 1998 to 2006; in Germany, Hungary and Iceland the increase was more than $8 \%$.

The European Trend is responding to kosovan students too, 53\% female are in Higher Education Institutions.

To show this male -female balance is Kosovo is very important to evaluate the kosovan migration from 1990-2010. Kosovan emigrant female, according to Kosovo Remittances Household Survey $2011,19 \%$ of female household heads in Kosovo have not completed primary education compared to men $5, \%$ and $19,1 \%$ kosovan emigrant women completed university or higher level compare with the Kosovo women in Kosovo where just 7,2 completed University level, and kosovan emigrant men household head $7,1 \%{ }^{21}$

This increase in the proportion of female graduates has not been seen as problematic in the vast majority of countries, primarily since the differences between the participation rates of women and men are not very big in most countries. Nevertheless, a report by the Higher Education Policy Institute (HEPI), an independent think-tank in the United Kingdom, highlights areas of possible concern for the future, arguing that this trend might have the potential to 'give rise to adverse stereotypes, particularly for men from disadvantaged socio-economic backgrounds' (HEPI 2009:101). At the national level, Finland and Sweden are somewhat concerned about this issue.

In Sweden, in January 2009, the Delegation for Gender Equality in Higher Education was commissioned with the task of supporting and proposing measures that promote gender equality

${ }^{21}$ An Overview of Migration in Kosovo - Kosovo Remittance Study 2012: 28 
in higher education. This body has been asked to pay special attention to the issue of genderrelated choice of academic courses as well as to the question of a decline in the proportion of men that apply for university programmes and courses. Nevertheless, despite these overall tendencies, comparing the proportion of women among graduates at ISCED level 5 and ISCED level 6 (i.e. at doctoral level) reveals that women are still slightly underrepresented among doctoral graduates. The percentage of female doctoral graduates in Kosovo is $37 \%$ and in the EU-27 is on average $44 \%$, and it is $50 \%$ or higher only in Bulgaria, Estonia, Italy, Cyprus, Latvia, Lithuania, Romania, Finland and Iceland. The proportion of women with a doctorate is below $40 \%$ in the French Community of Belgium, the Czech Republic, Malta and Liechtenstein. Nevertheless, in the case of Cyprus, Malta, Iceland and Liechtenstein, due to the very low absolute number of doctoral graduates, data on the proportion of women have to be interpreted carefully. In Turkey, interestingly, the proportion of women with doctorates is not much lower (41\%) than that of female graduates at ISCED level 5. Overall, these percentages have been relatively stable since 2004 but with a slightly increasing tendency. In Denmark, Slovenia and Finland, there has been an increase of more than $10 \%$, while Estonia is the only country where the proportion of women with doctorates has decreased since 2004. Women are even more under-represented among professors and academic staff in universities. In Kosovo is underrepresented among the academic and managerial staff in universities too, just $27,6 \%$ are women among the academic staff and 36\% among the administrative staff at the public Higher Education Institutions in Kosovo. The percentage of women among teaching staff at ISCED 5-6 levels is below $50 \%$ in all EU countries except Latvia and Lithuania. The proportion of female teachers and professors is particularly low in the Czech Republic, Germany, Greece, France, Italy, Hungary, Malta, the Netherlands, Austria and Slovenia. Nevertheless, it has to be noted that in the majority of countries, the percentage of women among academic staff has been slowly increasing since 1998. There has been more than a $30 \%$ increase in the Netherlands, Austria, Slovakia, Slovenia and the United Kingdom. The countries in which the relatively low proportion of female teachers in higher education has been fairly stable are Greece, France and Hungary. It has stabilised at a comparatively higher level in Poland and Iceland. In two countries, namely in the Czech Republic and Estonia (this latter is according to data from 2004) the proportion of women among academic staff has decreased since 1998 (Eurydice calculations based on Eurostat, 2009).

In Kosovo the number of students has increased rapidly from 1999 ca. 16000 students just in one public Higher Education Institutions, in academic year 2012/ 2013 are enrolled 106.577 in 4 public Higher Education Institutions and 25Private Higher Education Institutions. ${ }^{22}$ The salaries of academic staff are very attractive in Balkan Countries. (EACEA 2011:56). The salaries are higher in public $\mathrm{HEl}$ than those of comparable staff in the Ministry for all staff categories.

Results of both international and national surveys show how important the impact of social status is in this context. The interplay between gender, social class and ethnic background affects behaviour and consequently pupil performance. A policy focus on only one source of social

22 EACEA -Overview of the Higher Education Systems in the Tempus Partner Countries -Western Balkan2012:44 and the Kosovo Accreditation Agency 
inequality might hide the complexity of experiences within a specific group and lead to oversimplistic solutions (Tinklin et al., 2003).

Linking monitoring, evaluation and funding of Higher Education Institutions to gender equality criteria.

In Kosovo are not such a measures in place, the female academic staff doesn't have any significant non-salary benefits, such as child allowance, free or subsidized child care, free or subsidized housing, health insurance, maternity leave is just 6 months. The attractiveness to work at public $\mathrm{HEl}$ is very high despite the benefit packages are not the main reasons to be attracted to the positions in $\mathrm{HEI}$ but the salaries higher and the social status compare with the private HEI is represented. ${ }^{23}$

The main advantages of a job as academic staff in Kosovo is Employment stability, social status, opportunities for international mobility and research opportunities, but as the academic staff in public HEl are involved just 27\% women (at the University of Prishtina for academic year $2012 / 2013$ are $15 \%$ female as full time academic staff and $34 \%$ as part time academic staff) .

As main advantages of a job as academic staff are low salary and lack of research opportunities (EACEA 2011;89) so for that the academic staff has 2 or 3 jobs.

The statute (2008) of the University of Prishtina doesn't allow their academic staff to work as full time staff in two Institutions, but the full implementation of this Statute was encouraged and fully implemented in academic year 2014/2015. This implementation has impact in increasing the teaching and research quality at the whole university. In 2018 based on regulations of Accreditation Agency all academic staff can work just at one $\mathrm{HEl}$ as regular staff and in another Institution based on short term work contract.

Skills and motivation at the public HEl in Kosovo are main reasons for success, and as main reasons for lack of motivation of academic staff in EACEA survey are mention inadequate salaries $(32 \%)$, lack of reward mechanism (23\%), lack of research opportunities (15\%) and lack of time/heavy workload (12\%). The main weakness in terms of skills of academic staff was their lack of flexibility and resistance to change. In the on-survey from EACEA, unwillingness to implement changes is also on the most frequently mentioned weaknesses. Skills are considered satisfactory overall, language skills are not yet considered sufficient and for the administrative staff is lack of language and IT skills, followed by resistance to change ant lack of team working skills.

Gender equality issues might be included in lists of criteria for Higher Education Institutions (HEI) and evaluation and funding. The inclusion of a gender perspective in HEI development plans, for example, or the improved representation of women in $\mathrm{HEI}$ management bodies and academic staff might here be considered as criteria.

In the International Projects and Programmes such as Tempus and Erasmus Mundus, many good iniciatives in gender equity have taken place and the internationalization and modernization of

${ }^{23}$ EACEA- Human Resources Management in Public Higher Education in the Tempus Partner Countries 2011:51 
several institutions. However, it is neither sufficient nor sustainable to leave the task of human resources development and gender equity to these programmes, while project may be used as an initiator of new systems or processes, national authorities, together with institutions, should take on more responsibility for the development of human resources across the HE sector.

Linking gender equality in numerical terms to funding of higher education institutions, as is the case in some European countries, might be an effective approach for enhancing the representation of women (see Eurydice, 2008a). This can take the form of introducing gender equality criteria into funding formulas for calculating public grants for higher education institutions, as well as into 'performance contracts' (Eurydice 2008a, p. 57). For example, institutions need to include the gender composition of their staff in their strategic objectives linked to funding. (Waldman et al 2019, 125))

The funding formula for calculating the public grant is based on inclusive education and number of students and not based on performance and gender equity, but everywhere is supported the gender balance and many more measures to promote gender equality in schools and higher education institutions. Evidently any strategy or measure being piloted or adopted in this field needs to be monitored and evaluated regularly and adapted according to changing circumstances.

Looking at the comparative overview of policy concerns identified and measures taken, we can see that although the scale of individual initiatives in European countries is large, many countries lack an overall strategy and implementation plans which would form part of an effective gender equality policy. (Adler 2007, 38)

Education is a powerful instrument in changing attitudes and behaviour. Education systems, therefore, play an important role in fostering equal chances for everyone and in combating stereotypes; HEI have a duty to provide all students with the opportunity to know themselves and to discover their own identity, strengths and interests regardless of traditional gender expectations.

\section{Policy and Economic Engagement of Women}

The engaging women as political, social and economical actors can change policy and can make kosovan institutions more representative and effective. A growing body of evidence indicates that women bring unique experiences and contributions to discussions leading to peace and security, particularly environments that have experienced conflict. And this is also very relevant in Kosovo. Kosovo does have strong laws (Law 2004/2 approved on 19 February 2004) promoting gender equality and women's empowerment. And in this respect, Kosovo is ahead of many other countries. But these laws are not always effectively monitored or enforced.

The first women president in the Balkan region is President Atifete Jahjaga elected in April 2011 in Kosovo. A first women summit organised under the Pressidential Office gathered all donors and discussed the path to the gender equality not just in Kosovo but throughout the region and 
the world. The first president woman is a step forward in the kosovan leadership and she was very active on the international stage. The woman organization and the women in parliament worked together and shared conviction that together they can empower women and help shape a society in which all citizens share an equal voice. The summit highlights several key policy priorities.

Women are very visible at the highest levels of Kosovo's political scene. It is a woman president, and women form one-third of the Assembly, 3 Ministers are women and women are Deputy Prime Minister for legislation period 2010-2014.But in the executive high ministry positions are under representative and there are no women rectors at the public higher education institutions till now October 2015. The first Mayor Women was elected in the municipality of Gjakova in year from 2013 - 2017 Mrs. Mimoza Kusari.

If we talk about education, more Kosovo women than men are illiterate (Women and Men in Kosovo 2009:27) the most women at the university tend to specialize in such traditionally female studies as language, social sciences, health and education. With the result that they get lower paying jobs in the future or no jobs at all. The poor and middleclass women after finishing their studies, if they will not get any job, they have to marry or to go back to their patriarchal families in different villages.

Women in Kosovo have a low participation in the labor force and high unemployment. In 2018, the whole inactive labor force is estimated $60.8 \%$, within which $83.4 \%$ are women and $38.6 \%$ are men. The most serious problem in Kosovo is the youth unemployment rate. In the age group of 15-24 unemployment is the highest, $54 \% .{ }^{24}$ Women of working age are active in the labor market with only $16.6 \%$, compared to $61.4 \%$ of working-age men, and only $11.8 \%$, of women are employed compared to $45.5 \%$ of employed men. In Kosovo, women are mainly employed in the education, health and trade sectors (51.2\%). As opposed to this men are mainly employed in the sectors of trade, construction, and manufacture $(42.4 \%) .{ }^{25}$ Unemployment rate among women with primary education is $26.3 \%$, among women who have completed secondary education is $39.5 \%$, while $15.5 \%$ of women with university degrees are unemployed; finally, women with no school diploma are fully unemployed. ${ }^{26}$ (Report on Women's Right in Western Balkans)

Gender equality and women's empowerment is based on the employability and on economic position of women and the status of women in society. Unemployment is a problem for everyone in Kosovan society, but particularly for women. Only twenty-nine percent ${ }^{27}$ of women are represented in the labor force, and that is the lowest rate in Europe and Eurasia. The rate of female entrepreneurship is also in Kosovo the lowest in the region. Women are much less likely than men to own their own businesses. And when they do own businesses, it tends to be a microbusiness, with small profit margins and with very few employees.

\footnotetext{
24 Agency of Statistics of Kosovo, Labour Force Survey Q1 2018, available at: http://ask.rksgov.net/media/4349/labour-force-survey-q1-2018.pdf.

25 1lbid., p.10.

26 lbid., p.26.

27 Women and men in Kosovo 2009:44
} 
One the biggest impediment for women in entrepreneurship is access to credit. Law on proper rights and statistics of property women do not have property in general, for societal and traditional reasons, so they lack the collateral to get the loans that they need. There is legislation in place to address this issue, but again implementation is a challenge.

Housing titling often is suggested as a solution to gender discrimination, protecting women against the dispossession through abandonment, separation or divorce, and increase of women's bargaining power in household decision making. Mandatory joint titling for legally married couples provides the most secure rights for women. In 2008 and 2009 are just $8 \%$ female owned the house and $92 \%$ male compare with 2007 is an increase of $1 \%$.

\section{Summary and Recommendations}

Education is the basic key to Kosovo's future development as a successful, stable, and prosperous country. gender equality is essential to the success of all the economic development. Kosovo cannot get ahead if the women are left behind. EU Programmes and USAID are providing grants to support women in economic empowerment, education, combating violence, participation in politics, and even sports.

USAID is working with female entrepreneurs all over Kosovo, providing training to women-owned businesses, and supporting their initiative. Supporting the female entrepreneurs supports not just a family, but it empowered an entire community. It is a joint-responsibility, and one that can help entire communities.

On the political stage, it has been proved that engaging women can help make government institutions more representative and more effective. Women bring a unique perspective to decision-making in peace and security, to end conflict or to prevent conflict. It turns out that we are good at collaborating, communicating, and consensus-building. And these are the skills that the $21^{\text {st }}$ century needs.

Women are leading in the Balkan Crises; the women encouraged by European Commission are very committed and engaged to make progress and changes in Balkan countries. The new millennium brought the new crises; economic challenges, higher unemployment rate and political corruption. The women in Balkan are more carefully in the diplomacy and they are much more for consensus, dialogue and compromise. The women are more sensitive and stronger emotionally than man. The first Slovenian Lady Prime Minister Alenka Bratusek, ex Croatian Prime Minister Jadranka Kosor leaded her Country into the EU and finalized successfully Croatian Membership in the European Commission.

Now Kosovo has strong laws to promote gender equality and the empowerment of women. In this respect, Kosovo is ahead of many other countries. Women are visible at the highest level of Kosovo politics, including the president, the major, national assembly, key ministers, so it is fitting that Kosovo would take the lead to work on advancing these issues in this region. To be more 
efficient and active the women should be represented in leadership roles in all structures, in the government, and in the parliament, and not just at the national level, but at the local level too.

This progress in Kosovo is made thanks to the courage and determination of women - as well as men - who have been prepared to fight this battle. They must be equally courageous and determined.

Results of both international and national surveys show how important the impact of social status is in this context. The interplay between gender, social class and ethnic background affects behaviour and consequently pupil performance. A policy focus on only one source of social inequality might hide the complexity of experiences within a specific group and lead to oversimplistic solutions (Tinklin et al., 2003).

Organized women are more likely to act against corruption; therefore, more efforts are needed to invest in on-going community organizing, empowerment and the leadership development processes of grassroots women. (Priya Pillai)

Linking gender equality in numerical terms to funding of higher education institutions, as is the case in some European countries, might be an effective approach for enhancing the representation of women (see Eurydice, 2008a). This can take the form of introducing gender equality criteria into funding formulas for calculating public grants for higher education institutions, as well as into 'performance contracts' (Eurydice 2008a, p. 57). For example, institutions need to include the gender composition of their staff in their strategic objectives linked to funding.

On the policy framework, the Government adopted several specific instruments aiming at promoting a human rights-centred approach to public policy. They include an overall Human Rights Strategy and Action Plan, the Kosovo Programme for Gender Equality, and other sectorial legal and policy documents. Overall, their main shortcoming stands in the weak connection with the documents stating general Government policy, and a lack of specificity in terms of objectives, responsibilities and budgetary impact.

Challenges: Human Rights, lack of social and health care, violence against women and quality of education which have an impact in the quality of life of all citizens.

\section{References}

Adler, S., 2007: Libraries. In K. Myers, H. Taylor, S. Adler/ D. Leonard, eds.: Genderwatch: still watching. Stoke-On-Trent: Trentham, pp. 138-140.

Arnot, M., David, M./ Weiner, G., 1999: Closing the Gender Gap: Postwar educational and social change. Cambridge: Polity Press.

BMUKK (Bundesministerium für Unterricht, Kunst und Kultur) [Austrian Federal Ministry for Education, Arts and Culture], 2007: Gender \& Lesen. Geschlechtersensible Leseförderung: Daten, Hintergründe und Förderungsansätze. Wien: BMUKK. 
BMWF (Bundesministeriums für Wissenschaft und Forschung) [Austrian Federal Ministry of Science and Research], 2009: Datawarehouse Hochschulbereich. [Online] Available at: http://www.bmwf.gv.at/unidata [Accessed 19 October 2009].

Booth, C./ Bennett, C., 2002: Gender mainstreaming in the European Union: Towards a new conception and practice of equal opportunities? The European Journal of Women's Studies, 9(4), pp. 430-446. https://doi.org/10.1177/13505068020090040401

Brusselmans-Dehairs, C., Henry, G.F., Beller, M. \& Gafni, N., 1997: Gender differences in learning achievement: Evidence from cross-national surveys. Educational studies and documents 65 . Paris: UNESCO.

Canaj, K. (2020). Language Policy and Language Planning in Kosova. International Journal of Teaching \& Education, v VIIIn2. DOI:10.20472/TE.2020.8.2.003

EACEA- A Tempus Study 2012: Human Resources Management in Public Higher Education in the Tempus Partner Countries. Issue 10, June 2012.

EACEA - Tempus Study 2012: Overview of the Higher Education Systems in the Tempus Partner Countries. Issue 13 - November 2013.

Kosovo Remittance Study 2012.

Javidan, M., Bullough, A., \& Dibble, R. (2016). Mind the gap: Gender differences in global leadership selfefficacies. Academy of Management Perspectives. Volume 30, Issue 1, 59-73. https://doi.org/10.5465/amp.2015.0035

Ramsey, J. R., Lorenz, M.P. (2019). Every flow has its ebb: impact of flow on work family conflict and adjustment in global careers. Human Resources 2 Management Journal. DOI. 10.1111/17488583.12234, 30, 3, (441-460), (2019).

Kim, K.Y., Atwater, L. Jolly, Ph.M., Kim, M., Baik,K. (2019). The Vicious Cycle of Work Life: Work Effort Versus Career Development Effort. Group \& Organisation Management. https://doi.org/10.1177/1059601119880377

Waldman, D.A., Siegel, D.S., Stahl, G.K. (2019). Defining the Sociall Responsible Leader: Revisiting Issues in Responsible Leadership. Journal Leadership \&Organisational Studies. https://doi.org/10.1177\%2F1548051819872201 